\title{
Factors Associated with Poor Lymph Node Dissection of Colon Neoplasm
}

\section{Kolon Kanseri Cerrahisinde Yetersiz Lenf Nodu Çıkarılması ile İlişkili Risk Faktörleri}

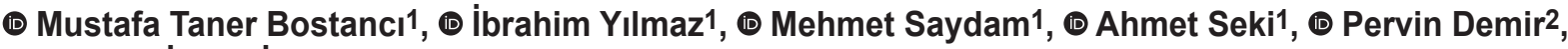 \\ (1) Gökşen İnanç İmamoğlu33, ๑ Aysun Gökçe 4 \\ 1 University of Health Sciences Turkey Dışkapı Yıldırım Beyazıt Training and Research Hospital, Clinic of General Surgery, Ankara, Turkey \\ ${ }^{2}$ Ankara Yıldırım Beyazıt University Faculty of Medicine, Department of Biostatistics and Medical Informatics, Ankara, Turkey \\ 3University of Health Sciences Turkey Dışkapı Yıldırım Beyazıt Training and Research Hospital, Clinic of Medical Oncology, Ankara, Turkey \\ ${ }^{4}$ University of Health Sciences Turkey Dışkapı Yıldırım Beyazıt Training and Research Hospital, Clinic of Pathology, Ankara, Turkey
}

\section{HIIIIII ABSTRACT}

\begin{abstract}
Aim: Dissection of $\geq 12$ lymph nodes is recommended for curative surgery of colon neoplasms. The aim was to determine the clinicopathological factors associated with poor lymph node dissection.

Method: Patient hospital records in those undergoing surgery due to stage 1-3 colon neoplasm, between January 2009 and December 2017 , were retrospectively evaluated. Univariate and multivariate analyses were performed to evaluate the clinical and pathological risk factors associated with poor lymph node dissection.

Results: The patient population during the study period numbered 388. Of these, $<12$ lymph nodes were dissected in $21.9 \%$. Tumor location in the left colon, large tumors, deep penetrating tumors and short surgical margins were found to be independent risk factors for poor lymph node dissection by univariate analysis. Male gender, left colon location, large-sized tumors and deep penetrating tumors were confirmed as being independent markers for poor lymph node dissection by multivariate analysis.

Conclusion: Adequate lymph node dissection for colon neoplasm patients has prognostic significance. Male patients, advanced pT stage neoplasm, and left colon tumors had an increased risk of poor lymph node dissection. Therefore, lymph node dissection should be undertaken particularly meticulously in these patients.
\end{abstract}

Keywords: Colon cancer, colectomy, poor lynph node dissection

\section{|IIIIIIII ÖZ}

Amaç: Kolon kanserinin küratif cerrahisinde $\geq 12$ lenf nodunun diseke edilmesi önerilmektedir. Bu çalışmada yetersiz lenf nodu diseksiyonuna etki eden klinikopatolojik faktörleri belirlemeyi amaçladık.

Yöntem: Ocak 2009-Aralık 2017 tarihleri arasında evre 1-3 kolon kanseri tanısıyla opere ettiğimiz hastalar retrospektif olarak incelenmiştir. Yetersiz lenf nodu diseksiyonu için risk faktörü olan klinik ve patolojik veriler tek değişkenli ve çok değişkenli analizlerle değerlendirilmiştir.

Bulgular: Çalışmaya 388 evre 1-3 kolon kanseri hasta dahil edilmiştir. Hastaların \%21,9'da <12 lenf nodu diseke edildiği tespit edilmiştir. Tek değişkenli analizde sol kolon lokalizasyonunun, büyük tümörlerin, derin penetrasyon gösteren tümörlerin ve kısa cerrahi sınırın yetersiz lenf nodu diseksiyonu için bağımsız risk faktörleri olduğu tespit edilmiştir. Çok değişkenli analizde ise erkek cinsiyetin, sol kolon lokalizasyonunun, büyük tümörlerin ve derin penetrasyon gösteren tümörlerin yetersiz lenf nodu diseksiyonu açısından bağımsız belirteçler olduğu tespit edilmiştir.

Sonuç: Hastaların büyük kısmında yeterli lenf nodu diseksiyonun sağlandığı çalışmamızda büyük, pT evresi ileri, sol kolon yerleşimli tümöre sahip erkek hastaların yetersiz lenf nodu diseksiyonu açısından artmış riske sahiptir.

Anahtar Kelimeler: Kolon kanseri, kolektomi, yetersiz lenf nodu disseksiyonu

Address for Correspondence/Yazışma Adresi: İbrahim Yılmaz, MD,

University of Health Sciences Turkey Dışkapı Yıldırım Beyazıt Training and Research Hospital, Clinic of General Surgery, Ankara, Turkey

E-mail: dribrahimyilmaz@yahoo.com ORCID ID: orcid.org/0000-0003-0759-0974

Received/Gelis Tarihi: 02.03.2021 Accepted/Kabul Tarihi: 25.03.2021

${ }^{\odot}$ Copyright 2021 by Turkish Society of Colon and Rectal Surgery

Turkish Journal of Colorectal Disease published by Galenos Publishing House. 


\section{Introduction}

Colon neoplasms are the most common malignant tumor of the gastrointestinal system worldwide and the leading cause of cancer-related morbidity and mortality in Western countries. Approximately $70-80 \%$ of colon neoplasms are diagnosed at localized disease level, and surgical resection is the treatment of choice. ${ }^{1}$ Curative surgery of colon neoplasms should include complete tumor resection with involved bowel segment and its mesentery with dissection of the draining lymph nodes.

Currently, the most important prognostic factors for colon neoplasm are the tumor node metastasis (TNM) staging system and the presence of residual tumor after resection. The presence of nodal metastasis is not only the most important prognostic factor but also the primary factor for adjuvant therapy decision making. ${ }^{2}$

Detection of all positive lymph nodes is essential for accurate staging, as inadequate lymph node dissection poses an absolute risk for inaccurate staging and thus deprivation of appropriate adjuvant therapy which has a significant effect on survival. $3,4,5$

There are different views on the minimum number of lymph nodes for adequate staging., ${ }^{5,6,7}$ However, many studies suggest that at least 12 lymph nodes should be examined for nodal evaluation of colon cancer. ${ }^{8,9,10}$

Institutional guidelines, including the American Joint Committee on Cancer, the American Society of Clinical Oncology, the National College of Surgeons, the National Quality Forum, and the National Comprehensive Cancer Network, state that at least 12 lymph nodes are required for the correct staging of colon neoplasm patient. ${ }^{11,12,13}$ Several factors have been shown to influence the number of lymph nodes removed. These include patient-specific and surgeonspecific factors and others related to pathological evaluation, not all of which can be optimized. ${ }^{14,15}$

The aim of this study was to determine the clinicopathological factors affecting inadequate lymph node dissection in patients with curative resection of colon neoplasms.

\section{Materials and Methods}

This study was a retrospective, single-centre study, comprised of colon cancer patients who underwent emergency and elective surgery between January 2009 and December 2017. Rectal neoplasms, synchronous colon neoplasms, colon neoplasms of familial polyposis, metastatic disease, palliative surgery patients, and patients who did not have adenocarcinoma following histopathological examination were excluded from the study. Only patients with stage 1-3 colon cancer were evaluated.
Preoperative laboratory analysis, colonoscopy, and imaging procedures including chest radiography and computed tomography, were performed in all elective surgery patients. The local Ethics Committee of University of Health Sciences Turkey, Dışkapı Yıldırım Beyazıt, Training and Research Hospital approved the study (date: 25.12.2017, no: 44/24). Written patient consent was not obtained because of the retrospective nature of the study.

All surgical specimens were fixed in 10\% formalin solution and then routinely placed in paraffin. Conventional methods of visual inspection and palpation were used to detect lymph nodes. Hematoxylin-eosin stained sections of all lymph nodes were examined microscopically. If mucin constituted $>50 \%$ of tumor volume histopathologically, the tumor was defined as mucinous carcinoma. Vascular invasion was defined as the presence of tumor cells along the venous endothelial surface, thrombosis of the venous lumen with tumor cells or destruction of the venous wall by tumor cells. The extraneural appearance of tumor cells was defined as "perineural invasion". In all pathology reports, tumor size and differentiation, proximal and distal surgical margins, pT staging, the total number of removed lymph nodes and the total number of involved lymph nodes were reported.

Neoplasms located in the region from the ileocecal valve to the distal of the transverse colon were defined as right colon neoplasms, and neoplasms located in the region from splenic flexure to rectosigmoid junction $(15 \mathrm{~cm}$ proximal from the anal canal) were defined as left colon neoplasm. Central vascular ligation was performed for both side neoplasms.

Neoplasms were pathologically classified according to the $8^{\text {th }}$ American Joint Committee on Cancer (AJCC) TNM classification. Samples with $<12$ removed lymph nodes constituted the inadequate dissection group. ${ }^{16}$

\section{Statistical Analysis}

The Shapiro-Wilk test was used to assess normality of distribution of data sets. Numerical variables are presented as mean \pm standard deviation and median (minimum to maximum range) while categorical variables are presented as number (percentage).

A univariate logistic regression model was used to calculate the effect of independent variables on the likelihood of obtaining an insufficient number of lymph nodes. As a result of univariate logistic regression analysis of clinically predicted variables that affected inadequate lymph node removal, variables with an error level below $0.25(\mathrm{p}<0.25)$ were identified as candidate variables for the multivariate model. A multivariate logistic regression model (Backward Wald) was established for candidate variables. In each step, the probability of entry into the logistic regression 
model was 0.05 , and the probability of exclusion from the model was 0.10 . In addition, $95 \%$ confidence intervals were determined for the odds ratio (OR) values obtained by logistic regression.

\section{Statistical Analysis}

Statistical analyses and calculations were performed using SPSS, version 21.0 (IBM Inc., Armonk, NY, USA) and MSExcel 2007. Statistical significance level was accepted as $p$ $<0.05$.

\section{Results}

Between January 2009 and December 2017, a total of 761 colorectal neoplasm patients were operated. After assessment of fit with the study inclusion criteria, 388 of 761 (50.98\%) stage 1-3 colon cancer patients were included in the study population (Figure 1).

Demographic characteristics of patients are shown in Table 1. Two hundred and four patients (52.6\%) were younger than 65 years, and 232 (59.8\%) were male. Adequate lymph node dissection ( $\geq 12$ nodes) was performed in 303 (78.1\%) and inadequate ( $<12$ nodes) was performed in 85 (21.9\%). The statistical numerical variables are shown in Table 2 .

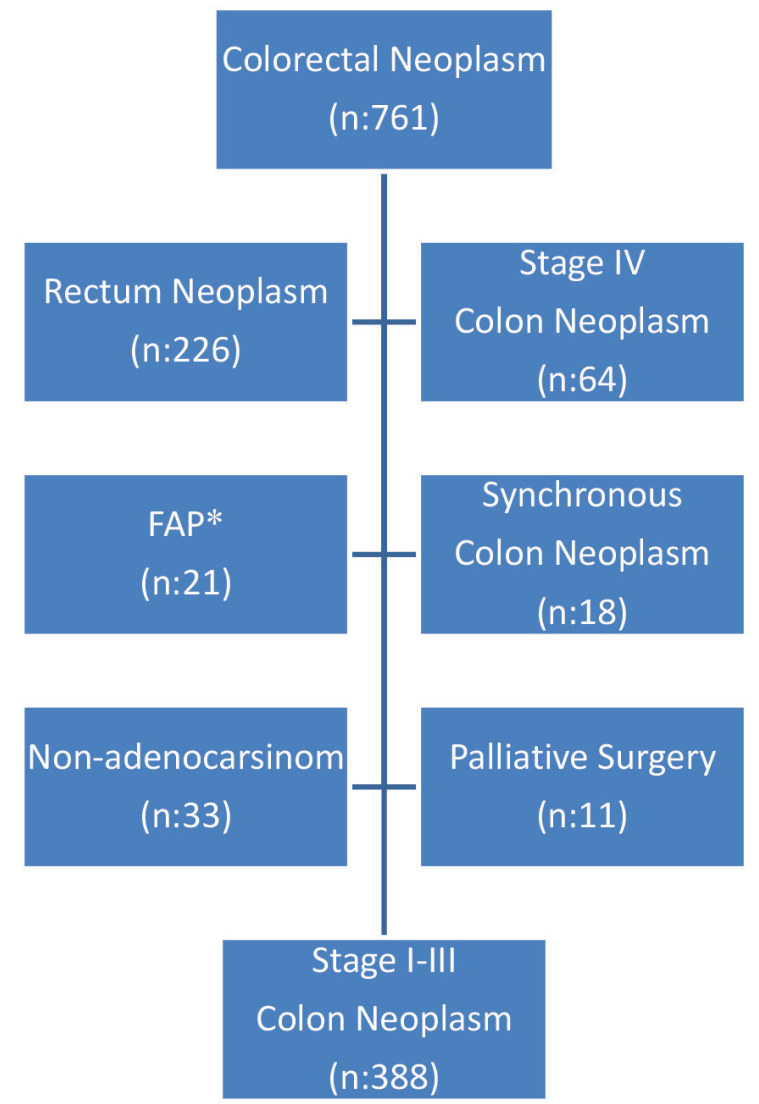

Figure 1. Selection of colorectal neoplasm patients' criterias (*Familial adenomatous polyposis)
The relationship between univariate logistic regression and the number of removed lymph nodes of the indicated independent variables was examined (Table 3). The probability of inadequate lymph node dissection was found to be 1.59 times higher in male patients but this was not significant $(\mathrm{p}=0.072)$. The probability of inadequate lymph node dissection was 2.79 times [95\% confidence interval (CI): 1.55-5.04] higher in tumors of the left colon than the right colon $(\mathrm{p}<0.001)$. The risk of inadequate lymph node assessment was higher in patients who did not have lymphovascular invasion (OR: 1.77) but this was not significant $(\mathrm{p}=0.053)$.

As a result of univariate analysis a number of variables were identified for inclusion in the multivariate logistic regression model. These variables included gender, location, tumor size, T-group, lymphovascular invasion and surgical margin. In the Enter model, there was a multiple connection problem between the T-group and the surgical margin. As a result of the stepwise model, the surgical border variable was not included in the model, whereas the T-group variable was included in the model. In the last model, the effect of gender, location, tumor size $(\geq 5 /<5 \mathrm{~cm})$ and T-group $(3+$ $4 / 1+2)$ variables were significant.

\section{Discussion}

Lymph node metastasis alone is the most important prognostic factor in colon cancer. ${ }^{17}$ The 5 -year survival rate is over $75 \%$ in patients without metastatic lymph nodes but decreases below 30\% in patients with lymph node invasion. ${ }^{18}$ Therefore, in order to perform accurate staging of colon cancer according to AJCC TNM classification, it is necessary to thoroughly examine the surgical specimen and determine the status of lymph node metastasis.

In many studies, it has been shown that total survival and disease-free survival rates are directly proportional with the number of removed lymph nodes. ${ }^{19,20}$ However, it has been reported that regional lymph node dissection is affected by many factors. ${ }^{14}$ Currently, the rate of adequate lymph node dissection ( $\geq 12$ lymph nodes) in colon cancer was reported to be $70 \% .^{2,19}$

The proportion of patients who underwent inadequate lymph node dissection in our cohort was $21.9 \%$, which is similar to the literature. However, in contrast to earlier studies, we could not find a correlation between lymph node dissection and patient age in colon cancer patients. Studies have reported that fewer lymph nodes are dissected in elderly patients whichmay be associated with the decrease in immunological and inflammatory reactions to cancer tissues in elderly patients. ${ }^{10,21}$ 
Table 1. Demographic characteristics of patients

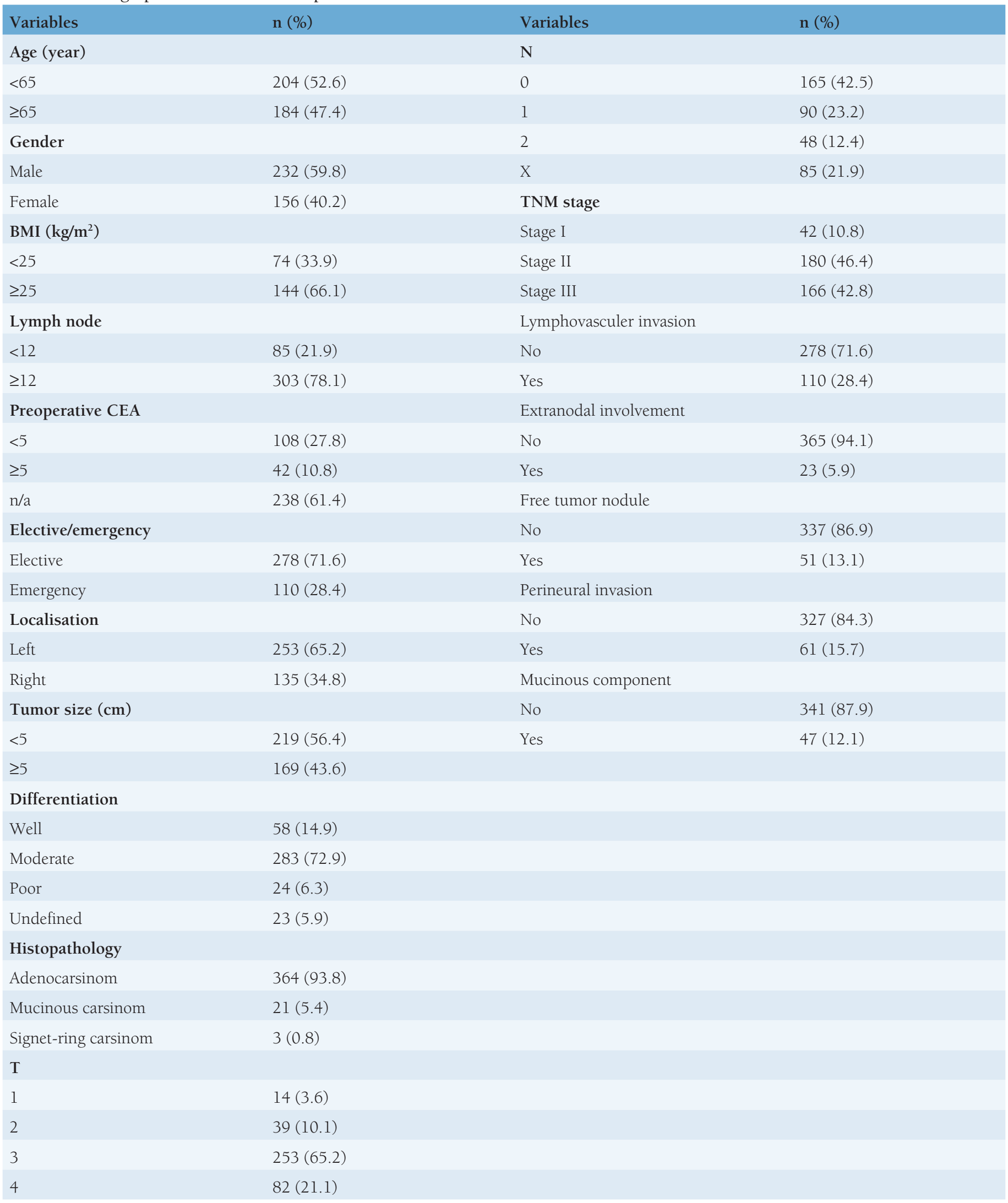

BMI: Body mass index, CEA: Carcinoembryonic antigen 
Table 2. The statistical numerical variables

$\begin{array}{llll}\text { Variables } & \mathbf{n} & \begin{array}{l}\text { Median } \\ (\text { min; max })\end{array} & \text { Mean } \pm \text { SD } \\ \text { Age } & 388 & 63.5(24 ; 91) & 62.93 \pm 11.72 \\ \text { BMI } & 218 & 26.63(16.51 ; 45.2) & 10.06 \pm 29.35 \\ \text { Preoperative CEA } & 150 & 2.4(0.1 ; 247) & 4.86 \pm 2.31 \\ \text { Size }(\mathrm{cm}) & 388 & 4.5(0 ; 19) & 19.56 \pm 11.79 \\ \text { LN } & 388 & 17(0 ; 116) & 1.36 \pm 2.70 \\ \text { LN positive } & 388 & 0.0(0.0 ; 22.0) & 6.21 \pm 4.86 \\ \text { Surgical margin }(\mathrm{cm}) & 388 & 5(0.2 ; 40) & \end{array}$

SD: Standart deviation, min: Minimum, max: Maximum, BMI: Body mass index, CEA: Carcinoembryonic antigen

As previously reported, male sex was found to be associated with inadequate lymph node dissection in our study, but this relationship remains unclear. Larger and deeper-penetrating (T3-4) tumors were associated with a greater number of lymph nodes dissected by the surgeon. This may be the result of more antigenic immune and inflammatory responses increasing the number and size of regional lymph nodes. ${ }^{10,22}$ As a result, lymph nodes were more easily identifiable for pathological examination. In our study, tumors in the left colon were associated with inadequate lymph node dissection, as many studies have reported, and this may be due to the surgeon avoiding a high anterior resection for distal sigmoid and rectosigmoid located neoplasms. ${ }^{23}$ Additionally, the vascular anatomy of the right colon and associated neoplasms allows the removal of an extended bowel segment and wider mesentery. ${ }^{15}$ Also, microsatellite instability, which is an essential pathway in tumor biology, is detected in $20-25 \%$ of right colon neoplasms, and this results in an increased propensity for metastatic locoregional lymph nodes. ${ }^{24}$

Close surgical margin is more common in sigmoid and rectosigmoid resections, and it is also associated with low numbers of lymph nodes being dissected. ${ }^{25}$ In our study, the relationship between the close surgical margin and low lymph node number was found to be statistically significant in univariate analysis but not significant in multivariate analysis.

Tekkis et al. ${ }^{21}$ reported that tumor differentiation was associated with the number of removed lymph nodes, so that poorly differentiated tumors had more lymph nodes removed compared with well or moderate differentiation neoplasms. We did not find any correlation between tumor differentiation and the number of lymph nodes removed.

Lymphovascular invasion, extranodal involvement, perineural involvement and free tumor nodule are indicators of tumor aggression. In a limited number of studies, their relationship with the number of removed lymph nodes could not be demonstrated. Gelos et al. ${ }^{26}$, in a retrospective study of 341 patients, showed that the presence of lymphovascular invasion did not correlate with the number of removed lymph nodes and this is in agreement with our findings.

Although some studies have reported low numbers of lymph node being removed in patients with a high body mass index (BMI ${ }^{27}$, the effect of BMI on the number of removed lymph nodes is still unclear. In our cohort there was no relationship between the number of lymph nodes removed in low-weight and normal-weight patients (BMI $<25 \mathrm{~kg} / \mathrm{m}^{2}$ ) and overweight and obese patients (BMI $>25 \mathrm{~kg} / \mathrm{m}^{2}$ ).

The number of lymph nodes removed depends on different factors, including quality of surgical specimen, pathological examination, and characteristics of the patient and neoplasm. The limitation of our study was that more than 10 surgeons treated patients and different pathologists examined specimens. However, our hospital can be considered as a high-volume centre where approximately 100 colorectal cancer surgeries are performed annually. Moreover, some studies reported that higher hospital volume, more experienced surgeons and pathologists improve the quality of lymph node evaluation. ${ }^{28}$ However, some other studies indicated that there was no statistical relationship between them. ${ }^{29}$ Elferink et al. ${ }^{30}$ reported that increased workload and, in particular that the pathologists could not perform a more detailed examination, so that there was an indirect relationship between the number of lymph nodes removed and the hospital volume.

\section{Conclusion}

Adequate lymph node removal in colon surgery has prognostic significance for the patient, and this was achieved in most of the curative resections in this study. There is an 
Table 3. Univariate and multiple logistic regression model results

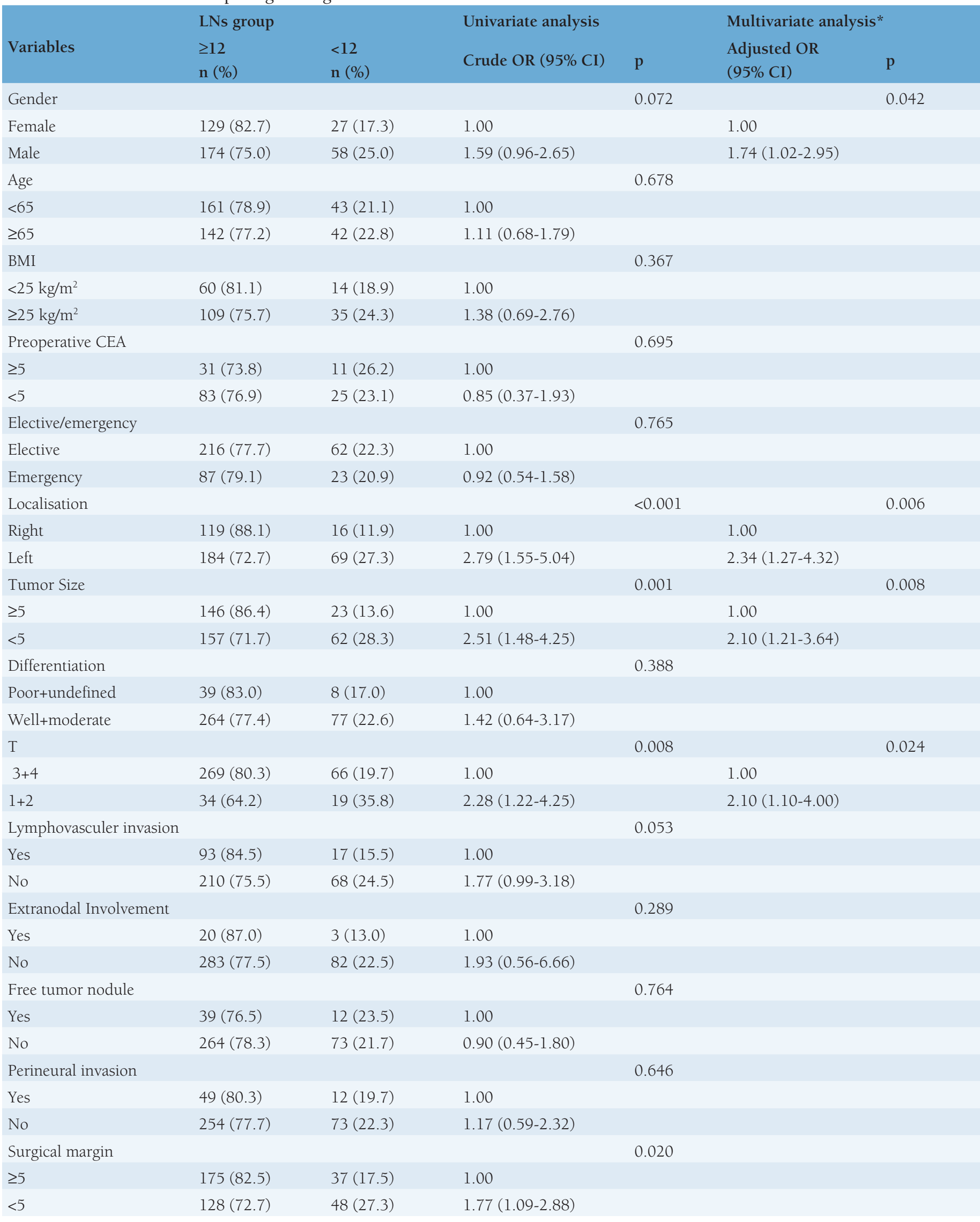

OR: Odds ratio, CI: Confidence interval $/$ Backward Wald model accurate classification rate $=78.6 \%$, Exp $($ constant $)=0.060$ 
increased risk for inadequate lymph node dissection in male patients, in patients with left colon tumors, and in patients without locally advanced tumors. Therefore, lymph node dissection should be undertaken particularly meticulously in these patients.

\section{Ethics}

Ethics Committee Approval: The local Ethics Committee of University of Health Sciences Turkey, Dışkapı Yıldırım Beyazit Training and Research Hospital approved the study (date: 25.12.2017, no: 44/24).

Informed Consent: Written patient consent was not obtained because of the retrospective nature of the study.

Peer-review: Internally and externally peer reviewed.

\section{Authorship Contributions}

Surgical and Medical Practices: M.T.B., İ.Y., Concept: M.T.B., İ.Y., Design: M.T.B., İ.Y., Data Collection or Processing: M.S., A.S., P.D., G.İ.I., A.G., Analysis or Interpretation: P.D., Literature Search: M.S., A.S., G.İ.̇., A.G., Writing: M.T.B., İ.Y.

Conflict of Interest: No conflict of interest was declared by the authors.

Financial Disclosure: The authors declared that this study received no financial support.

\section{References}

1. Nelson H, Petrelli N, Carlin A, Couture J, Fleshman J, Guillem J, Miedema B, Ota D, Sargent D, National Cancer Institute Expert Panel. Guidelines 2000 for colon and rectal cancer surgery. J Natl Cancer Inst 2001;93:583596

2. Huh JW, Kim CH, Kim HR, Kim HR, Kim YJ. Factors predicting oncologic outcomes in patients with fewer than 12 lymph nodes retrieved after curative resection for colon cancer. J Surg Oncol 2012;105:125-129.

3. Namm J, Ng M, Roy-Chowdhury S, Morgan JW, Lum SS, Wong JH. Quantitating the impact of stage migration on staging accuracy in colorectal cancer. J Am Coll Surg 2008;207:882-887.

4. Tsai HL, Yeh YS, Yu FJ, Lu CY, Chen CF, Chen CW, Chang YT, Wang JY Predicting factors of postoperative relapse in T2-4NOMO colorectal cancer patients via harvesting a minimum of 12 lymph nodes. Int J Colorectal Dis 2009;24:177-183

5. Shanmugam C, Hines RB, Jhala NC, Katkoori VR, Zhang B, Jr JAP, Bumpers HL, Grizzle WE, Eltoum IE, Siegal GP, Manne U. Evaluation of lymph node numbers for the adequate staging of Stage II and III colon cancer. J Hematol Oncol 2011;4:25

6. Iachetta F, Reggiani BL, Marcheselli L, Gregoria CD, Cirilli C, Messinese S, Cervo GL, Postiglione R, Emidio KD, Pedroni M, Longinotti E, Federico M, de MP. Leon Lymph node evaluation in stage IIA colorectal cancer and its impact on patient prognosis: a population-based study. Acta Oncol 2013;52:1682-1690.

7. Gönen M, Schrag D, Weiser MR. Nodal staging score: a tool to assess adequate staging of node-negative colon cancer. J Clin Oncol 2009;27:61666171.

8. Shia J, Wang H, Nash GM, Klimstra DS. Lymph node staging in colorectal cancer: revisiting the benchmark of at least 12 lymph nodes in R0 resection. J Am Coll Surg 2012;214:348-355.
9. Chen HH, Chakravarty KD, Wang JY, Changchien CR, Tang R. Pathological examination of 12 regional lymph nodes and long-term survival in stages I-III colon cancer patients: an analysis of 2,056 consecutive patients in NE. Reftwo branches of the same institution. Int J Color Dis 2010;25:13331341.

10. Tsai HL, Huang CW, Yeh YS, Ma CJ, Chen CW, Lu CY, Huang MY, Yang IP, Wang JY. Factors affecting the number of lymph nodes harvested and the impact of examining a minimum of 12 lymph nodes in stage I-III colorectal cancer patients: a retrospective single-institution cohort study of 1167 consecutive patients. BMC Surg 2016;16:17.

11. American Joint Committee on Cancer. Cancer staging manual (5th ed): Springer; 1997: pp. 83-91.

12. Bilimoria KY, Bentrem DJ, Stewart AK, Talamonti MS, Winchester DP, Russell TR, Ko CY. Lymph node evaluation as a colon cancer quality measure: a national hospital report card. J Natl Cancer Inst 2008;100:13101317.

13. Nelson H, Petrelli N, Carlin A, Couture J, Fleshman J, Guillem J, Miedema B, Ota D, Sargent D, National Cancer Institute Expert Panel. Guidelines 2000 for colon and rectal cancer surgery. J Natl Cancer Inst 2001;93:583596.

14. Sarli L, Bader G, Iusco D, Salvemini C, Mauro DD, Mazzeo A, Regina G, Roncoroni L. Number of lymph nodes examined and prognosis of TNM stage II colorectal cancer. Eur J Cancer 2005;41:272-279.

15. Nathan H, Shore AD, Anders RA, Wick EC, Gearhart SL, Pawlik TM Variation in lymph node assessment after colon cancer resection: patient, surgeon, pathologist, or hospital? J Gastrointest Surg 2011;15:471-479.

16. Jessup JM, Goldberg RM, Asare EA, et al. AJCC cancer staging manual. 8th edition. New York: Springer-Verlag 2017:251-274.

17. Brunicardi FC, Andersen DK, Billiar TR, Dunn DL, Hunter JG, Matthews JB, Pollock RE. Schwartz's principles of surgery. 10th ed. New York: McGraw-Hill Education; 2015: 1175-1241.

18. Le Voyer TE, Sigurdson ER, Hanlon AL, Mayer RJ, Macdonald JS, Catalano PJ, Haller DG. Colon cancer survival is associated with increasing number of lymph nodes analyzed: a secondary survey of Intergroup Trial INT0089. J Clin Oncol 2003;21:2912-2919.

19. Aan de Stegge WB, van Leeuwen BL, Elferink MA, de Bock GH. The Evaluation of More Lymph Nodes in Colon Cancer Is Associated with Improved Survival in Patients of All Ages. PLoS One 2016;11:e0155608.

20. Chang GJ, Rodriguez-Bigas MA, Skibber JM, Moyer MA. Lymph node evaluation and survival after curative resection of colon cancer: Systematic review. J Natl Cancer Inst 2007;99:433-441.

21. Tekkis PP, Smith JJ, Heriot AG, Darzi AW, Thompson MR, Stamatakis JD, Association of Coloproctology of Great Britain and Ireland. A national study on lymph node retrieval in resectional surgery for colorectal cancer. Dis Colon Rectum 2006;49:1673-1683.

22. Baxter NN, Virnig DJ, Rothenberger DA, Morris AM, Jessurun J, Virnig BA Lymph node evaluation in colorectal cancer patients: a population-based study. J Natl Cancer Inst 2005;97:219-225.

23. Morikawa T, Tanaka N, Kuchiba A, Nosho K, Yamauchi M, Hornick JL, Swanson RS, Chan AT, Meyerhardt JA, Huttenhower C, Schrag D, Fuchs CS, Ogino S. Predictors of lymph node count in colorectal cancer resections: data from US nationwide prospective cohort studies. Arch Surg 2012;147:715-723.

24. Søreide K, Nedrebø BS, Søreide JA, Slewa A, Kørner H. Lymph node harvest in colon cancer: influence of microsatellite instability and proximal tumor location. World J Surg 2009;33:2695-2703

25. Morikawa T, Tanaka N, Kuchiba A, Nosho K, Yamauchi M, Hornick JL, Swanson RS, Chan AT, Meyerhardt JA, Huttenhower C, Schrag D, Fuchs CS, Ogino S. Predictors of lymph node count in colorectal cancer resections: data from US nationwide prospective cohort studies. Arch Surg 2012;147:715-723. 
26. Gelos M, Gelhaus J, Mehnert P, Bonhag G, Sand M, Philippou S, Mann B.Factors influencing lymph node harvest in colorectal surgery. Int J Colorectal Dis 2008;23:53-59.

27. Kuo YH, Lee KF, Chin CC, Huang WS, Yeh CH, Wang JY. Does body mass index impact the number of LNs harvested and influence long-term survival rate in patients with stage III colon cancer? Int J Colorectal Dis 2012;27:1625-1635.

28. Evans MD, Barton K, Rees A, Stamatakis JD, Karandikar SS. The impact of surgeon and pathologist on lymph node retrieval in colorectal cancer and its impact on survival for patients with Dukes' stage B disease. Colorectal Dis 2008;10:157-164

29. Bilchik AJ, DiNome M, Saha S, Turner RR, Wiese D, McCarter M, Hoon DS, Morton DL. Prospective multicenter trial of staging adequacy in colon cancer: preliminary results. Arch Surg 2006;141:527-533.

30. Elferink MA, Wouters MW, Krijnen P, Lemmens VE, Jansen-Landheer ML, van de Velde CJ, Siesling S, Tollenaar RA. Disparities in quality of care for colon cancer between hospitals in the Netherlands. Eur J Surg Oncol 2010;36(Suppl 1):S64-S73. 